\title{
Efficacy of blastodermal cells and CRISPR/CAS9 method in the creation of transgenic duck (Anas Platyrhynchos)
}

O. M. Konoval ${ }^{1,2}$, P. V. Korol ${ }^{3}$, S. O. Kostenko ${ }^{4}$, P. P. Tabaka ${ }^{1}$, L. Lizhi ${ }^{1}$, A. M. Chepiha ${ }^{4}$, M. S. Doroshenko ${ }^{4}$, O. V. Sydorenko ${ }^{3}$, P. P. Dzhus ${ }^{3}$, N. P. Svyrydenko ${ }^{4}$, T. V. Lytvynenko ${ }^{4}$, B. Xingchen ${ }^{1}$, H. Xuetao ${ }^{5}$, L. Li ${ }^{5}$, M. V. Drahulian ${ }^{6}$, E. R. Kostyuk ${ }^{4}$, P. O. Filipova ${ }^{4}$

${ }^{1}$ Institute of Animal Husbandry and Veterinary Science, Zhejiang Academy of Agricultural Sciences 198 Shiqiao Road, Hangzhou, Zhejiang, China, 310021

${ }^{2}$ Ukrainian Laboratory of Quality and Safety of Agricultural Products National University of Life and Environmental Sciences of Ukraine 7, Mashynobudivnykiv Str., Chabany, Kyiv region, Ukraine, 08162

${ }^{3}$ Institute of Animal Breeding and Genetics nd. a. M.V. Zubets of NAAS of Ukraine

1, Pohrebniaka Str., Chubyns'ke, Kyivs'ka obl., Ukraine, 083213

${ }^{4}$ National University of Life and Environmental Sciences of Ukraine 15, Heroiv Oborony St., Kyiv, Ukraine, 03041

${ }^{5}$ Zhuji Guowey Poultry Development Co, Ltd, Ltd. 1, Gujing Road, Wangjiajing, Zhuji, Zhejiang, China, 311813

${ }^{6}$ Rinderunion Baden-Württemberg Genetik GmbH, Hopfenweilerweg 20,88339 Bad Waldsee, Germany parus_major@ukr.net

The aim of the work was to develop a methodology for the creation of transgenic chimeras of ducks by using donor blastodermal cells after transfection with DNA vector and Lipofectamine 2000® (Invitrogen, USA). The CRISPR/Cas9 system with homology directed repair (HDR) was used to edit the target site of the duck genome. Materials and research methods. Transgenic duck chimeras were created using donor blastodermal cells after transfection with plasmid DNA and Lipofectamine 2000. To edit the target region of the duck genome, we used the CRISPR / cas9 system with HDR. The EGFP reporter gene was used as the transgene. Conclusions. Среди выживших фертильных животных было 13/20 животных G0 (65\%): $10 / 12(83,3 \%)$ Of the 200 eggs, in which the transfected blastodermal cells were introduced, 20 offspring were obtained, including 8 males and 12 females. Thus, the survival of embryos was $10 \%$. Among the surviving fertile animals, $13 / 20$ were animals G0 (65 \%): 10/12 (83.3\%) females and 3/8 (37.5\%) males. The procedure of obtaining chimeras has a stronger effect on the survival and fertility of male chimeras. From 13 of 20 birds G0, we received a total of 197 offspring (including 117 (59.4\%) daughters and 80 (40.6\%) sons), 59 of which were EGFP-

(C) 2021 O. M. Konoval et al.; Published by the Institute of Molecular Biology and Genetics, NAS of Ukraine on behalf of Biopolymers and Cell. This is an Open Access article distributed under the terms of the Creative Commons Attribution License (http://creativecommons.org/licenses/by/4.0/), which permits unrestricted reuse, distribution, and reproduction in any medium, provided the original work is properly cited 
positive (30.3\%), including 10 males (16.9\%) and 49 females $(83.1 \%)$. The technique used by us can be successfully applied in further researches and for creation of a transgenic duck.

Ke y w o r d s: CRISPR/Cas9,EGFP,Transgenic Duck, Blastodermal Cells, chimera

\section{Introduction}

Transgenesis has now become a routine procedure that allows obtaining uniquely valuable pharmaceutical producing animals [1-3], models of evolution $[4,5]$ and hereditary diseases [6], and a valuable animal protein for human nutrition [7].

A transgenic animal is defined as an animal that has a transgene stably incorporated into its germline and is able to transmit the transgene to its offspring [8]. To obtain a transgenic animal, it is necessary to edit the zygote genome. However, the strategy used for mammals [9] was not successful when editing the avian genome because of the differences in the reproductive system and embryo development in ovo [10].

The bird has unique economically valuable features consisting of reduced resource costs and short time from the start of the experiment up to obtaining transgenic birds. Due to the compact size of birds, control and zootechnical manipulations (artificial insemination, feeding, egg collection, etc.) do not require highly skilled labor and most of the technological processes of growing and keeping the birds are automated. Short interval between generations (6-7 months), speed of reproduction (up to 200 ducklings from one duck per year) and high feed conversion rate are considerably superior to other farm animals [11]. The $54 \%$ of egg white in its chemical composition is represented by ovalbumin $[1,12]$, which allows more efficient purification of recombinant pro- teins after transgenesis, while the glycosylation profile close to that of humans, makes it possible to obtain the proteins toxic for mammals, so the bird egg is considered to be the best model for the production of recombinant proteins [13-15]. Transgenic EGFP construct had no effect on duck egg productivity [16].

Three methods are mostly used to obtain transgenic birds: 1) transfection of the DNA vector with sperm $[17,18]$; 2) DNA injections into the embryonic cavity of a newly laid egg [19-21]; 3) introduction of donor cells [2224]. Certain complications have been established in the implementation of the transgene with the introduction of DNA vector using the method of transfection with sperm [17].

In a freshly incubated egg - stage X according to Eyal-Giladi and Kochav, 1976 (EGK-X), the embryo has developed up to 50000-60000 cells [25], therefore, methods of obtaining transgenic bird chimeras have become more widespread in poultry [11], using blastodermal cells produced from non incubated eggs (EGK-X) and PGCs - primordial germ cells - primary reproductive cells produced from blood of 2.5-3-day-old embryos (stages 13-17 according to Hamburger and Hamilton 1951); and from the gonads of 5-7-day-old embryos (stages 26-31) [26]. It has been shown that the blastodermal cells freshly isolated from the EGK-X stage chicken embryos can contribute to all somatic tissues as well as to the germline after injection 
of the EGK-X recipient embryos into the subgerminal cavity [27-31].

The use of primordial germ cells (PGC) in chickens and quail is considered to be the most effective method for transferring genetic information to the next generation $[32,33]$. Moreover, the methods mediated by PGC require a lot of time, expensive equipment for PGC selection and cultivation, as well as highly qualified laboratory staff.

After the first transgenic chicken was created using a viral vector, various approaches to obtaining genetically modified chicken were tested [11].

Currently, the CRISPR/Cas9 genome editing system is considered to be an advanced technology for avian transgenesis [10, 34], since this system is more specific and versatile compared to other site-specific nucleases such as ZFNs (Zinc-finger nucleases) and TALENs (Transcription activator-like effector nuclease) $[35,36]$. To create double-strand DNA breaks (DSB) in the target genome site using the CRISPR/Cas9 system, only the sequence of 20-nucleotide guiding sgRNA should be changed, whereas the construction of ZFNs and TALENs is labor intensive and their specificity is lower, ZFN: from 5 to $7 \mathrm{bp}$, and TALEN: from 12 to $20 \mathrm{bp}$ [37, 38]. Doublestrand DNA breaks (DSB) stimulate the mechanisms of cellular DNA repair, including nonhomologous end joining (NHEJ) and homology directed repair (HDR) [39] when the donor DNA is injected together with CRISPR/Cas9 [40].

The main part of research on the creation of transgenic birds was done on chickens and quails [41-43, 22, 13]. However, the technology of creating transgenic ducks using blasto- dermal cells is hampered by the peculiarities of the waterfowl's eggs shell, which contains wide pores [44] and provides ways for contamination of the embryo by bacterial infections.

Therefore, the aim of the work was to develop a methodology for the creation of transgenic chimeras of ducks by using donor blastodermal cells after transfection with DNA vector with the help of Lipofectamine 2000. The CRISPR/Cas9 system with homology directed repair (HDR) was used to edit the target site of the duck genome. The EGFP reporter gene was used as a transgene $[45,46]$.

\section{Materials and Research Methods}

Research bird. The study was conducted on Shanma and Shaoxing poultry. The poultry were kept in breeding facilities of Zhejiang Guowei Technology Co. LTD (Zhuji, China), which is a research platform of the Institute of Animal Husbandry and Veterinary Medicine of the Zhejiang Academy of Agricultural Sciences (Hangzhou, China).

All experiments with animals were carried out in accordance with the provisions of the European Convention on the Protection of Spine Animals used for research and other scientific purposes. The experiment was conducted in three stages during 2016-2018s. The birds were kept in individual cages in the vivarium. The first stage began in February 2016 and included transgene injection, egg incubation, and identification of offspring (G0) with wing markers (Fig. 1). The second stage began in March 2017, the samples (blood, feathers, sperm, biopsy sample) were taken from the birds for DNA isolation and identification of the presence of the transgene by PCR method, 
as well as a mating campaign was conducted to determine the transfer of the transgene to offspring, the G1 descendants were received. The third stage began in March 2018 and included blood sampling from the offspring (G1), transgene determination.

Transgenic construction design. Integration of the EGFP reporter gene into the duck genome was performed using homology directed repair after double-strand breaks (DSBs) by the Cas 9 system. The plasmid containing the Cas9 gene was obtained from Addgene (http:// www.addgene.org/42230/). The plasmids encoding RNA guides (pBR322-sgRNA1, pBR322-sgRNA2) and the plasmid with the EGFP reporter gene and homologous regions of the genomic locus (pBR322-HDR-EGFP) were modeled on the basis of NCBI «Anas platyrhynchos Spindlin 1 (SPIN1)» (Gene ID: 101791720). The plasmids are described in

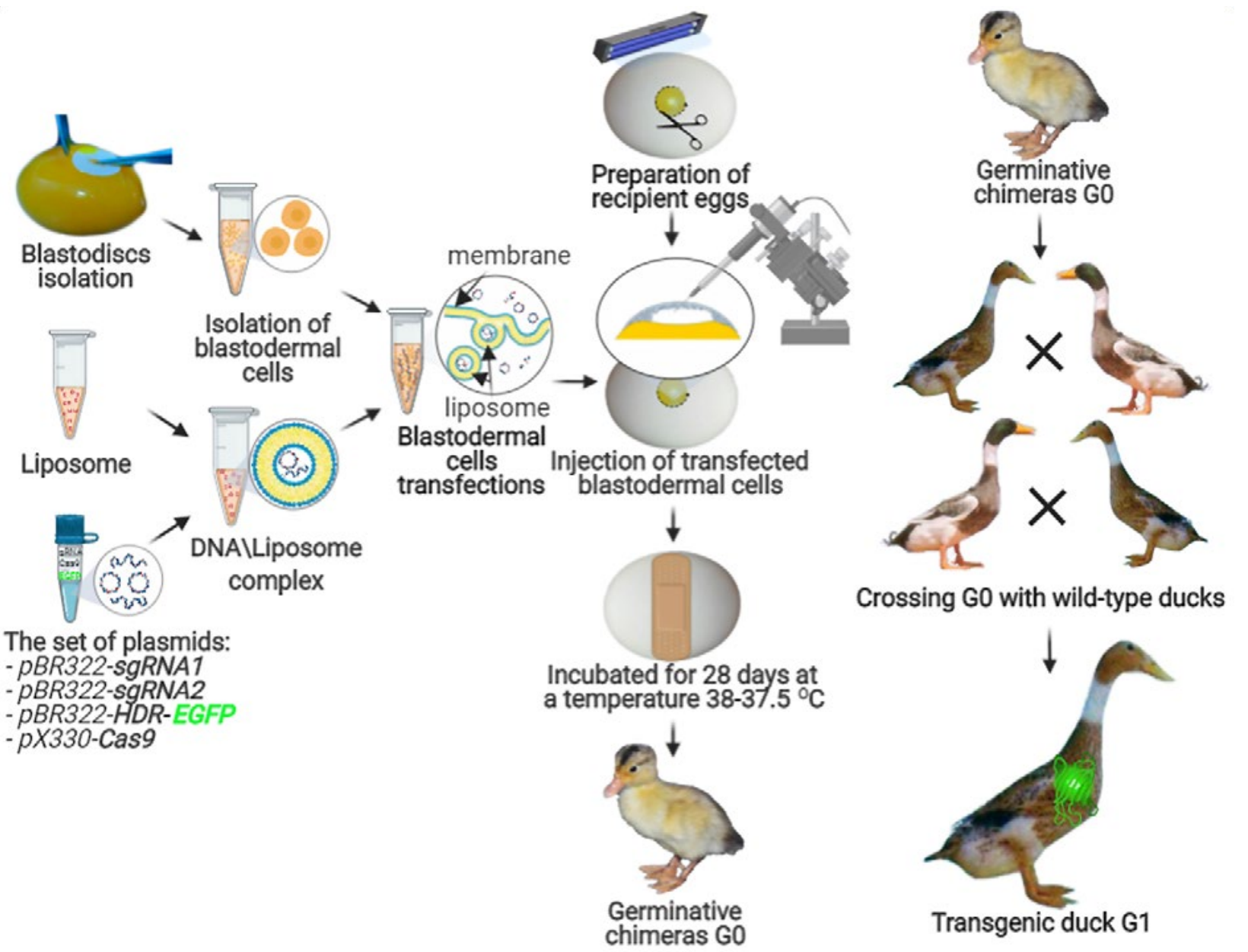

Created in BioRender.com bio

Fig. 1. Scheme of the experiment on the creation of transgenic chimeras 
more detail in our previous work, where we used sperm to create transgenic ducks [17,47].

Isolation of blastodermal cells. Blastodermal cells were isolated by the method developed by M. T. Tagirov on chickens [48]. Blastodermal cells were isolated from embryos of the Shaoxing breed, at stage EGK-X by means of a filtration papery ring [49]. Each blastodisk was washed twice from the yolk in a solution of phosphate-buffered saline (PBS). Then 10-12 blastodiscs were transferred using Pasteur pipette into $1 \mathrm{ml}$ of PBS containing $0.25 \%$ trypsin, $0.04 \%$ ethylenediaminetriacetic acid (EDTA), incubated for $10 \mathrm{~min}$ at $37^{\circ} \mathrm{C}$ and then centrifuged (10 s at $\left.1500 \mathrm{rpm}\right)$. Newly precipitated cells were resuspended in $1 \mathrm{ml}$ of RPMI 1640 culture medium containing $10 \%$ fetal bovine serum. The cell suspension was concentrated by centrifugation $(10 \mathrm{~s}$ at $1500 \mathrm{rpm}$ ) with further removal of $0.7 \mathrm{ml}$ of supernatant. Then the cells were resuspended in the remained medium.

Preparation of the DNA|Lipofectamine 2000 complex, transfection of blastodermal cells. For transfection of blastodermal cells, two solutions were prepared simultaneously: 1) solution 1. $30 \mu \mathrm{l}$ of OPTI-MEM $+6 \mu$ of Lipofectamine 2000 - incubated at room temperature for $5 \mathrm{~min}$; 2) solution 2. $30 \mu \mathrm{l}$ of OPTI-MEM $+4 \mu \mathrm{l}$ of plasmid DNA (25 ng/ ml of each vector: sgRNA1, sgRNA2, HDREGFP, Cas9) — incubated for $5 \mathrm{~min}$. Further, solution 1 and solution 2 were mixed and incubated for another $20 \mathrm{~min}$.

DNA/Lipofectamine 2000 complex was added to the precipitated blastodermal cells and incubated at $37.8^{\circ} \mathrm{C}$ for 4 hours.

Preparation of recipient eggs. The recipients were Shanma embryos at stage EGK-X.
For a more viable introduction of transfected blastodermal cells (TBCs) into the recipient's gonads, it was necessary to decrease the total level of primordial germ cells in the recipient's gonads. For this purpose, the recipient eggs were exposed to ultraviolet irradiation for one hour before the injection [50].

To gain access to the embryo, a $0.7-\mathrm{cm}$ opening was cut in the shell. The prepared TBCs were injected into the subgerminal cavity using a micro-needle injector (up to $70 \mu \mathrm{m}$ in diameter). Each embryo was injected with 2-3 $\mu \mathrm{L}$ of the suspension containing approximately 600 TBCs.

After TBCs injection into the recipients' subgerminal cavity, RPMI 1640 culture medium (with a mixture of ampicillin and streptomycin) was added with a pasteurized pipette to complete the filling so that no air was left in the eggs, then the donor eggs protein was applied around the cut openings as glue, and covered with a piece of UV-sterilized food film, $3 \times 3 \mathrm{~cm}$ in size, which was additionally fastened over the openings in the eggs with $2 \times 5 \mathrm{~cm}$ patch. Then the eggs were incubated for 28 days at a temperature of 38-37.5 ${ }^{\circ} \mathrm{C}$.

Selection of samples for DNA isolation. Samples of feathers, blood, and sperm were taken for DNA extraction. In each animal, two or three feathers were plucked from the chest and placed in individual tubes. From the brachial vein (Vena cutanea ulnaris) 1-2 $\mathrm{ml}$ of blood was collected in a vacuum tube with anticoagulant (EDTA). Sperm samples from males were taken by the transverse body massage [51].

All samples, after selection, were frozen and stored at $-20{ }^{\circ} \mathrm{C}$ until DNA was isolated. 
EGFP identification. Identification of transgenic DNA was performed by PCR. We used two primers located within the EGFP to amplify a $903 \mathrm{bp}$ fraction: the anterior one (5' GTGTACGGTGGGGAGGTC 3') and the posterior one (5' AAATGTGGTGGTGGCTGAT TATG $\left.3^{\prime}\right)$.

The program of the polymerase chain reaction included

- Initial stage at $94{ }^{\circ} \mathrm{C}, 3 \mathrm{~min}, 35$ cycles

- denaturation at $94^{\circ} \mathrm{C}, 15$ seconds

- evaporation at $55^{\circ} \mathrm{C}, 15$ seconds

- elongation at $72{ }^{\circ} \mathrm{C}, 30$ seconds

- final stage at $72{ }^{\circ} \mathrm{C}, 3 \mathrm{~min}$.
The obtained PCR product was sequenced, the resulting sequence was compared with the sequence of the EGFP gene in the NCBI base, the result of the comparison is $100 \%$ identity. PCR and sequencing experiments were performed by Genery Biotechnology Company (Shanghai, China)

(http://www.generay.com.cn/english)

Identification of chimerism by microsatellite loci. Analysis of the chimerism of $\mathrm{G} 0$ offspring was performed by assessing the phenotype and genotype of three generations of ducks P, G0, G1 at microsatellite loci. A total of 19 microsatellite loci were used for the

Table 1. Description of microsatellite loci used for analysis of three generations of ducks

\begin{tabular}{|c|c|c|c|c|c|}
\hline № & Locus & & Sequence of primers & Fluorescent dyes & $\begin{array}{c}\text { Annealing } \\
\text { temperature, }{ }^{\circ} \mathrm{C}\end{array}$ \\
\hline \multirow[t]{2}{*}{1} & \multirow[t]{2}{*}{ APL2 } & APL2-F & CGCTCTTGGCAAATGTCC & \multirow[t]{2}{*}{ FAM } & \multirow[t]{2}{*}{60} \\
\hline & & APL2-R & GATTCAACCTTAGCTATCAGTCTCC & & \\
\hline \multirow[t]{2}{*}{2} & \multirow[t]{2}{*}{ APL11 } & APL11-F & TTGCATCAGGGTCTGTATTTTC & \multirow[t]{2}{*}{ HEX } & \multirow[t]{2}{*}{60} \\
\hline & & APL11-R & AACTACAGGGCACCTTATTTCC & & \\
\hline \multirow[t]{2}{*}{3} & \multirow[t]{2}{*}{ APL12 } & APL12-F & AAGAGACACTGAGAAGTGCTATTG & \multirow[t]{2}{*}{ FAM } & \multirow[t]{2}{*}{60} \\
\hline & & APL12-R & AGTTGACCCTAATGTCAGCATC & & \\
\hline \multirow[t]{2}{*}{4} & \multirow[t]{2}{*}{ APL23 } & APL23-F & GCTGAGATGCTCCCAGGAC & \multirow[t]{2}{*}{ HEX } & \multirow[t]{2}{*}{60} \\
\hline & & APL23-R & GAAGAGGCAGTGGCAACG & & \\
\hline \multirow[t]{2}{*}{5} & \multirow[t]{2}{*}{ APL36 } & APL36-F & TCCACTGGGTGCAAACAAG & \multirow[t]{2}{*}{ HEX } & \multirow[t]{2}{*}{60} \\
\hline & & APL36-R & ATGCTTTGCTGTTGGAGAGC & & \\
\hline \multirow[t]{2}{*}{6} & \multirow[t]{2}{*}{ APL80 } & APL80-F & TTGCCTTGTTTATGAGCCATTA & \multirow[t]{2}{*}{ HEX } & \multirow[t]{2}{*}{58} \\
\hline & & APL80-R & GGATGTTGCCCCACATATTT & & \\
\hline \multirow[t]{2}{*}{7} & \multirow[t]{2}{*}{ APL79 } & APL79-F & CATCCACTAGAACACAGACATT & \multirow[t]{2}{*}{ FAM } & \multirow[t]{2}{*}{58} \\
\hline & & APL79-R & ACATCTTTGGCATTTTGAA & & \\
\hline \multirow[t]{2}{*}{8} & \multirow[t]{2}{*}{ APL77 } & APL77-F & GTATGACAGCAGACACGGTAA & \multirow[t]{2}{*}{ FAM } & \multirow[t]{2}{*}{55} \\
\hline & & APL77-R & TCACTTGCTCTTCACTTTCTTT & & \\
\hline \multirow[t]{2}{*}{9} & \multirow[t]{2}{*}{ SMO10 } & SMO10-F & CATTGTTCATTGTTTCTTCTTCA & \multirow[t]{2}{*}{ HEX } & \multirow[t]{2}{*}{55} \\
\hline & & SMO10-R & TCCTAGCGACAGCAATTCTAATG & & \\
\hline 0 & SMO13 & SMO13-F & GGGCTTGAGGCATACACTCCCTA & FAM & 58 \\
\hline & & SMO13-R & АССАТСТТССТТТССТСССААСС & & \\
\hline
\end{tabular}


analysis [52, 53], of which only 10 were polymorphic (Table 1).

\section{Research results}

After preparation and transfection of blastodermal cells, injections were performed in 200 recipient eggs that were incubated before hatching. To control embryonic development, three ovoscopies were performed during the incubation period (at day[s] 8, 15 and 25). During the first incubation period $95(47.5 \%)$ of the eggs perished, $15(7.5 \%)$ of the eggs perished during the second incubation period, and $70(35.0 \%)$ of the eggs perished during the third incubation period.

Of the 200 eggs, into which the transfected blastodermal cells were injected, 20 siblings were obtained, including 8 males and $12 \mathrm{fe}$ males. Thus, the survival rate of embryos was $10 \%$. Among the surviving fertile were $13 / 20$ animals: $10 / 12(83.3 \%)$ females and $3 / 8$ (37.5\%) males (Table 2). This can indicate that the procedure of chimera acquisition has a stronger effect on the survival and fertility

Table 2. Transmission of EGFP to the next generation by chimeric transgenic ducks

\begin{tabular}{|c|c|c|c|c|c|c|c|c|c|c|}
\hline \multirow{3}{*}{$\begin{array}{c}\begin{array}{c}\text { Founder } \\
\text { number } \\
(\mathrm{G} 0)\end{array} \\
29\end{array}$} & \multirow{3}{*}{$\begin{array}{c}\text { Sex } \\
\text { Female }\end{array}$} & \multirow{3}{*}{$\begin{array}{c}\begin{array}{c}\text { Number of } \\
\text { descendants } \\
\text { (G1) }\end{array} \\
33\end{array}$} & \multicolumn{6}{|c|}{ Number of transgenic descendants } & \multirow{3}{*}{$\begin{array}{c}\begin{array}{c}\text { Number of } \\
\text { descendants } \\
\text { analyzed for MS }\end{array} \\
13\end{array}$} & \multirow{3}{*}{$\begin{array}{c}\begin{array}{c}\text { Found alleles } \\
\text { which were } \\
\text { not in parents }\end{array} \\
4\end{array}$} \\
\hline & & & \multicolumn{2}{|c|}{ Totally } & \multicolumn{2}{|c|}{ Females } & \multicolumn{2}{|c|}{ Males } & & \\
\hline & & & 13 & $39.4 \%$ & 12 & $92.3 \%$ & 1 & $7.7 \%$ & & \\
\hline 45 & Female & 9 & 2 & $22.2 \%$ & 1 & $50.0 \%$ & 1 & $50.0 \%$ & 9 & 1 \\
\hline 46 & Female & 12 & 4 & $33.3 \%$ & 3 & $75.0 \%$ & 1 & $25.0 \%$ & 11 & 4 \\
\hline 47 & Female & 12 & 1 & $8.3 \%$ & 1 & $100.0 \%$ & 0 & $0.0 \%$ & 7 & 2 \\
\hline 48 & Female & 13 & 3 & $23.1 \%$ & 3 & $100.0 \%$ & 0 & $0.0 \%$ & 11 & 3 \\
\hline 49 & Female & 13 & 2 & $15.4 \%$ & 2 & $100.0 \%$ & 0 & $0.0 \%$ & 8 & 2 \\
\hline 50 & Female & 20 & 7 & $35.0 \%$ & 6 & $85.7 \%$ & 1 & $14.3 \%$ & 11 & 3 \\
\hline 51 & Female & 15 & 6 & $40.0 \%$ & 5 & $83.3 \%$ & 1 & $16.7 \%$ & 13 & 5 \\
\hline 52 & Female & 19 & 4 & $21.1 \%$ & 4 & $100.0 \%$ & 0 & $0.0 \%$ & 10 & 5 \\
\hline 53 & Female & 6 & 4 & $66.7 \%$ & 4 & $100.0 \%$ & 0 & $0.0 \%$ & 6 & 1 \\
\hline 27 & Male & 8 & 3 & $37.5 \%$ & 2 & $66.7 \%$ & 1 & $33.3 \%$ & 8 & 5 \\
\hline 28 & Male & 21 & 7 & $33.3 \%$ & 6 & $85.7 \%$ & 1 & $14.3 \%$ & 19 & 7 \\
\hline 30 & Male & 16 & 3 & $18.8 \%$ & 0 & $0.0 \%$ & 3 & $100.0 \%$ & 16 & 11 \\
\hline \multicolumn{2}{|c|}{$\begin{array}{l}\text { Totally from the } \\
\text { females }\end{array}$} & 152 & 46 & $30.3 \%$ & 41 & $89.1 \%$ & 5 & $10.9 \%$ & 99 & $30(30.3 \%)$ \\
\hline \multicolumn{2}{|c|}{$\begin{array}{l}\text { Totally from the } \\
\text { males }\end{array}$} & 45 & 13 & $28.9 \%$ & 8 & $61.5 \%$ & 5 & $38.5 \%$ & 43 & $23(53.5 \%)$ \\
\hline \multicolumn{2}{|l|}{ Totally } & 197 & 59 & $29.9 \%$ & 49 & $83.1 \%$ & 10 & $16.9 \%$ & 142 & $53(37.3 \%)$ \\
\hline
\end{tabular}


of males. This refers both to the number of those who survived $8 / 20(40 \%)$ - males, $12 / 20(60 \%)$ females and to the fertility of survived animals of different status.

In order to identify G0 chimerism, we analyzed G0 and G1 microsatellites. The animals that had alleles in their fathers were identified (Table 2).

From 13 out of $20(\mathrm{G} 0)$ birds, a total of 197 offspring were obtained (incl. 117 (59.4\%) daughters and 80 (40.6\%) sons), of which 59 were EGFP-positive (30.3\%), including 10 males $(16.9 \%)$ and 49 females $(83.1 \%)$ (Fig. 2).

Out of 12 chimeric ducks (G0), ten were pregnant and 152 ducks (G1) were obtained

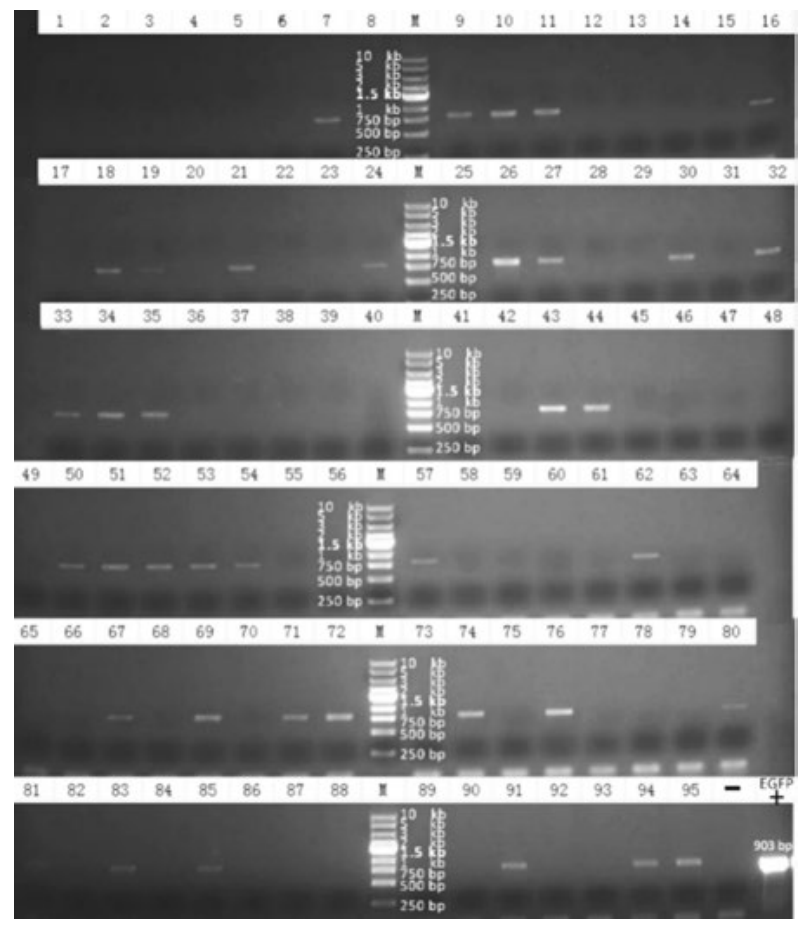

Fig. 2. Photographs of electrophoretic separation of PCR products by detecting EGFP gene sequence in the DNA of cells from them (including $94(61.8 \%)$ daughters and $58(38.2 \%)$ sons). 46 (30.3\%) of all G1 from females (G0) were transgenic. G0 females gave 5 transgenic sons $(10.9 \%)$ and 41 transgenic daughters $(89.1 \%)$. Nine out of ten G0 females transmitted the transgene only to their daughters, which may indicate that the construct may have been incorporated into the $\mathrm{W}$ chromosome and passed from mother to daughter. Only one female equally $(50 \%$ females, $50 \%$ males) passed on to transgenic offspring, which may indicate the location of the embedded structure in the autosome and gender-independent inheritance.

In this case, the unequal transmission of the transgenic construct to the offspring of different sexes was observed and the chimeric animals carried the primary germ cells of the recipient and donors. Among the donor cells of chimeras there were both ZZ and ZW. Thus, a chimeric female could give oocytes with a $\mathrm{W}$ and $\mathrm{Z}$ ratio that did not correspond to the classical 50:50. Among her offspring there could be individuals obtained from donor $\mathrm{ZZ}$, that is why one could expect a frequent transfer of Z-chromosome and a greater number of sons than daughters in chimera females.

Among the eight male chimeras, only three produced offspring. A total of 45 offspring were obtained from pregnant ducks, of which 13 were transgenic $(28.9 \%)$, including 5 $(38.5 \%)$ males and 8 females $(61.5 \%)$. Nine transgenic males did not give offspring, DNA analysis of their bodies and ejaculate confirmed their chimerism and the presence of a transgenic construct in all of them. Among the offspring obtained from two (out of three fertile) males $\mathrm{G} 0$, the percentage of transgenic daughters was $66.7 \%$ and $85.7 \%$, and the 
third male passed the transgene only to his sons.

In case of the presence of donor ZW cells in males, more daughters could be expected from such individuals (due to the fact that from the father they would receive the $\mathrm{W}$-chromosome of the donor and in combination with the $\mathrm{Z}$-chromosome of the mother would give a female), as well as lower fertility (because the $\mathrm{W}$-chromosome of the donor from the father in conjunction with the $\mathrm{W}$-chromosome of the mother gives a non-viable combination of $W W$ ). This can explain the presence of a greater number of daughters than sons in male chimeras as well as the reduced reproductive ability. Transmission of the transgenic construct to only sons of male \#30 can indicate that the daughters with constructs in the Z-chromosome from the father do not survive.

Some data suggest that germline chimeras show significant changes in sex hormone levels in the ovaries and blood plasma, which may affect their reproductive capacity [54].

\section{Discussion}

Thus, taking into account the results of transmission of the transgenic structure from $\mathrm{G} 0$ to G1 siblings, we should note that all cases can be analyzed as the results of independent events, that occurred during transfection of donor blastodermal cells or recipient cells after donor cells were transferred into the embryo together with construct DNA and Lipofectamine 2000. Belonging to the offspring of donors among the offspring obtained from G0 individuals was confirmed only in $37.3 \%$. Comparison of our results with the data of other researchers conducted on different species of birds using different stages of construction and vector application (Table 3) shows that the majority of studies were conducted on chickens. The construct was introduced at stages X [19-21] and 14-17 HH [22, 55-57, 23, 24].

Genome editing was performed using piggyBac transposon $[22,19,55]$, retroviral vector [57], lentivirus vector [29, 21], CRISPR Cas9 Lipofectamine 2000 [23, 24]. The data shown in the table indicate that the highest yield of transgenic individuals was observed in the studies by Park, T. S., \& Han, J. Y. (2012) [22], where all 6 animals were transgenic. Almost half of their siblings were transgenic, which can indicate the autosomal type of construction succession. Wang, Z.-B., Du, Z.-Q., (2018) obtained $68.7 \%$ of surviving chickens after the introduction of the construct by using PGC, among which $59.2 \%$ were transgenic. The transmission of the transgene to the next generation was only $1.2 \%$ [56].

Transfection of PGCs with Lipofectamine 2000 using the CRISPR $\backslash$ Cas 9 editing system made it possible to obtain $3.1 \%$ of F0 animals, of which $62.5 \%$ were transgenic [23]. Oishi, I., Yoshii, K., (2018) showed the transmission of the transgenic construct to $19.7 \%$ of the descendants of transgenic chimeras [24]. Jordan, B. J., Vogel, S.B. (2014) showed a high survival rate of embryos (52.5\%) after direct injection into blastodisc cavity, $100 \%$ of the surviving offspring were transgenic [19], however, none of them passed transgene to the next generation. When using direct injection of exogenous DNA into the blastodermal disc cavity, bird survival ranged from 4.8 to $62.7 \%$, and successful transmission to the next generation was observed in $0.77 \%-15.1 \%$ [ 20 , $21,56]$. Thus, compared to the direct injection 
O. M. Konoval, P. V. Korol, S. O. Kostenko et al.

Table 3. Effectiveness of the use of direct injections and PGC

\begin{tabular}{|c|c|c|c|c|c|c|c|}
\hline Species & Injected at stage & Transgenesis method & Vector & Received (G0) & Transgenic (G0) & Transgenic (G1) & By: \\
\hline Chickens & $\begin{array}{c}14-15 \mathrm{HH} \\
(50-60 \mathrm{~h}) \\
\end{array}$ & $\begin{array}{c}\text { piggyBac } \\
\text { transposon } \\
\end{array}$ & PGC & 6 & $\begin{array}{c}6 \backslash 6 \\
(\mathbf{1 0 0} \%) \\
\end{array}$ & $\begin{array}{c}228 \backslash 459 \\
\mathbf{( 4 9 , 7} \%) \\
\end{array}$ & 22 \\
\hline Chickens & Stage X & $\begin{array}{l}\text { piggyBac } \\
\text { JetPEI }\end{array}$ & $\begin{array}{c}\text { Direct } \\
\text { injection }\end{array}$ & $\begin{array}{c}42 \backslash 80 \\
(\mathbf{5 2 , 5} \%) \\
\end{array}$ & $\begin{array}{c}42 \backslash 42 \\
(\mathbf{1 0 0} \%) \\
\end{array}$ & $0 \backslash 150$ & 19 \\
\hline Chickens & $14-15 \mathrm{HH}$ & $\begin{array}{c}\text { piggyBac } \\
\text { Lipofectamine } 2000 \\
\end{array}$ & PGC & $\begin{array}{c}136 \backslash 198 \\
(68,7) \\
\end{array}$ & $\begin{array}{c}16 \backslash 27 \\
\mathbf{( 5 9 , 2} \%) \\
\end{array}$ & $\begin{array}{c}1 \backslash 81 \\
(\mathbf{1}, \mathbf{2} \%) \\
\end{array}$ & 56 \\
\hline Chickens & $14-15 \mathrm{HH}$ & $\begin{array}{c}\text { Retroviral Vector } \\
\text { Lipofection }\end{array}$ & $\begin{array}{c}\text { Direct } \\
\text { injection }\end{array}$ & $\begin{array}{l}32 \backslash 51 \\
(62,7)\end{array}$ & $\begin{array}{c}32 \\
(\mathbf{1 0 0} \%) \\
\end{array}$ & $\begin{array}{c}6 \backslash 181 \\
(3,3 \%) \\
\end{array}$ & 55 \\
\hline Chickens & $15 \mathrm{HH}$ & retroviral vector & $\begin{array}{c}\text { Direct } \\
\text { injection }\end{array}$ & $\begin{array}{l}21 \backslash 74 \\
(\mathbf{2 8 , 4 )} \\
\end{array}$ & $\begin{array}{c}21 \\
(\mathbf{1 0 0} \%) \\
\end{array}$ & & 57 \\
\hline Chickens & Stage $\mathrm{X}$ & $\begin{array}{c}\text { FIV-lentivirus } \\
\text { vector }\end{array}$ & $\begin{array}{c}\text { Direct } \\
\text { injection }\end{array}$ & $\begin{array}{c}10 \backslash 208 \\
(\mathbf{4 , 8 )}\end{array}$ & $\begin{array}{c}10 \\
(\mathbf{1 0 0} \%) \\
\end{array}$ & $\begin{array}{c}4 / 518 \\
(\mathbf{0 . 7 7} \%) \\
\end{array}$ & 20 \\
\hline quail & Stage $\mathrm{X}$ & lentiviral vector & $\begin{array}{c}\text { Direct } \\
\text { injection }\end{array}$ & $\begin{array}{c}8180 \\
(\mathbf{1 0} \%) \\
\end{array}$ & $\begin{array}{c}8 \\
(\mathbf{1 0 0} \%) \\
\end{array}$ & $\begin{array}{c}19 \backslash 126 \\
(\mathbf{1 5 , 1} \%) \\
\end{array}$ & 21 \\
\hline Chickens & 14-17 HH. & $\begin{array}{c}\text { CRISPR } \backslash \text { Cas9 } \\
\text { Lipofectamine } 2000 \\
\end{array}$ & PGCs & $\begin{array}{c}8 \backslash 260 \\
(\mathbf{3 , 1} \%) \\
\end{array}$ & $\begin{array}{c}5 \backslash 8 \\
(62.5 \%) \\
\end{array}$ & & 23 \\
\hline Chickens & $14-16 \mathrm{HH}$ & $\begin{array}{c}\text { CRISPR } \backslash \text { Cas9 } \\
\text { Lipofectamine } 2000\end{array}$ & PGCs & 4 & $\begin{array}{c}4 \\
(100 \%)\end{array}$ & $\begin{array}{c}31 \backslash 157 \\
(\mathbf{1 9 , 7} \%)\end{array}$ & 24 \\
\hline Ducks & Stage X & $\begin{array}{c}\text { CRISPR } \backslash \text { Cas9 } \\
\text { Lipofectamine } 2000\end{array}$ & $\begin{array}{l}\text { Blastodermal } \\
\text { cells }\end{array}$ & $\begin{array}{c}20 \backslash 200 \\
(10.0 \%)\end{array}$ & $\begin{array}{c}7 / 20 \\
(35.0 \%) \\
\end{array}$ & $\begin{array}{c}59 \backslash 197 \\
(29.9 \%) \\
\end{array}$ & 58 \\
\hline Ducks & Stage $X$ & $\begin{array}{c}\text { CRISPR } \backslash \text { Cas } 9 \\
\text { Lipofectamine } 2000\end{array}$ & $\begin{array}{c}\text { Direct } \\
\text { injection }\end{array}$ & $\begin{array}{c}9 \backslash 300 \\
(3.0 \%)\end{array}$ & $\begin{array}{c}4 \backslash 9 \\
(44.4 \%)\end{array}$ & $\begin{array}{c}37 \backslash 102 \\
(36.3 \%)\end{array}$ & 59 \\
\hline
\end{tabular}

of exogenous DNA into the blastodermal disc cavity, the PGC method is more successful in the transgene transmission to the next generation.

\section{Conclusions}

Transgenic duck chimeras were created using donor blastodermal cells after transfection with DNA vector and Lipofectamine 2000. To edit the target region of the duck genome, we used the CRISPR/Cas9 system with homologous directional reduction (HDR). The EGFP reporter gene was used as the transgene. Of the 200 eggs, in which the transfected blastodermal cells were introduced, 20 offspring were obtained, including 8 males and 12 females. Thus, the survival of embryos was $10 \%$. Among the surviving fertile were 13/20 animals G0 (65\%): 10/12 (83.3\%) females and $3 / 8(37.5 \%)$ males. The procedure of obtaining chimeras has a stronger effect on the survival and fertility of male chimeras.

From 13 of 20 birds G0, a total of 197 offspring (including $117(59.4 \%)$ daughters and $80(40.6 \%)$ sons $)$ were received, of which 59 were EGFP-positive (30.3\%), including 10 males $16.9 \%)$ and 49 females $(83.1 \%)$. The technique used by us can be successfully applied in further researches and at creation of a transgenic duck. 


\section{REFERENCES}

1. Lillico SG, McGrew MJ, Sherman A, Sang HM. Transgenic chickens as bioreactors for protein-based drugs. Drug Discov Today. 2005; 10(3): 191-6.

2. Oishi I, Kim S, Yoshii K, Esteban CR, Izpisua Belmonte JC. Cre-LoxP-regulated expression of monoclonal antibodies driven by an ovalbumin promoter in primary oviduct cells. BMC Biotechnol. 2011; 11: 5 .

3. Woodcock ME, Idoko-Akoh A, McGrew MJ. Gene editing in birds takes flight. Mamm Genome. 2017; 28(7-8): 315-23.

4. Kim GD, Lee JH, Song S, Kim SW, Han JS, Shin SP, Park BC, Park TS. Generation of myostatin-knockout chickens mediated by D10A-Cas9 nickase. FASEB J. 2020; 34(4): 5688-96.

5. Lee J, Kim D, Lee K. Muscle Hyperplasia in Japanese Quail by Single Amino Acid Deletion in MSTN Propeptide. Int J Mol Sci. 2020; 21(4): 1504.

6. Hamernik DL. Farm animals are important biomedical models. Anim Front. 2019; 9(3): 3-5.

7. Devlin RH, Sakhrani D, Tymchuk WE, Rise ML, and Goh B. Domestication and growth hormone transgenesis cause similar changes in gene expression in coho salmon (Oncorhynchus kisutch). Proceedings of the National Academy of Sciences of the United States of America. 2009; 106(9): 3047-52.

8. Wheeler $M B$, Walters EM, Clark SG. Transgenic animals in biomedicine and agriculture: outlook for the future. Anim Reprod Sci. 2003; 79(3-4): 265-289.

9. Clark D, Pazdernik N. Transgenic Animals. In: Biotechnology. 2nd ed. Elsevier: "Academic Cell", 2015; 850p.

10. Lee J, Kim D, Lee K. Current Approaches and Applications in Avian Genome Editing. Int J Mol Sci. 2020; 21(11): 3937.

11. Doran T, Challagulla A, Cooper C, Tizard M, Jenkins $K$. Genome editing in poultry-opportunities and impacts. Natl Inst. Biosci J. 2016; 1.

12. Peñas E, di Lorenzo C, Uberti F, Restani P. Allergenic proteins in enology: a review on technological applications and safety aspects. Molecules. 2015; 20(7): 13144-64.
13. Lillico $S G$, Sherman A, McGrew MJ, Robertson CD, Smith J, Haslam C, Barnard P, Radcliffe PA, Mitrophanous KA, Elliot EA, Sang HM. Oviductspecific expression of two therapeutic proteins in transgenic hens. Proc Natl Acad Sci U S A. 2007; 104(6): 1771-6.

14. Park TS, Lee HJ, Kim KH, Kim JS, Han JY. Targeted gene knockout in chickens mediated by TALENs. Proc Natl Acad Sci U S A. 2014; 111(35): 12716-21.

15. Zhu L, van de Lavoir MC, Albanese J, Beenhouwer DO, Cardarelli PM, Cuison S, Deng DF, Deshpande S, Diamond JH, Green L, Halk EL, Heyer BS, Kay RM, Kerchner A, Leighton PA, Mather CM, Morrison SL, Nikolov ZL, Passmore DB, Pradas-Monne A, Preston BT, Rangan VS, Shi M, Srinivasan M, White SG, WintersDigiacinto P, Wong S, Zhou W, Etches RJ. Production of human monoclonal antibody in eggs of chimeric chickens. Nat Biotechnol. 2005; 23(9): 1159-69.

16. Korol P, Kostenko S, Konoval O, Lu L, Li L. Egg productivity of EGFP-transgenic ducks. Animal Sci Food Technol. 2019; 10(3): 20-6.

17. Konoval O, Korol P, Tabaka P, Kostenko S, Lizhi L, Chepiha A, Doroshenko M, Drahulian M, Xingchen B, Xu-etao H, Liumeng L. Generation of transgenic ducks by CRISPR/Cas9-mediated gene insertion combined with the sperm-mediated gene transfer (SMGT). Biopolym Cell. 2019; 35(6): 427-36.

18. Collares T, Campos VF, De Leon PM, Cavalcanti PV, Amaral MG, Dellagostin OA, Deschamps JC, Seixas FK. Transgene transmission in chickens by sperm-mediated gene transfer after seminal plasma removal and exogenous DNA treated with dimethylsulfoxide or N,N-dimethylacetamide. J Biosci. 2011; 36(4): 613-20.

19. Jordan BJ, Vogel S, Stark MR, Beckstead RB. Expression of green fluorescent protein in the chicken using in vivo transfection of the piggyBac transposon. J Biotechnol. 2014; 173: 86-9.

20. Kwon MS, Koo BC, Kim D, Nam YH, Cui XS, $\operatorname{Kim} \mathrm{NH}, \operatorname{Kim}$ T. Generation of transgenic chickens expressing the human erythropoietin (hEPO) gene 
in an oviduct-specific manner: Production of transgenic chicken eggs containing human erythropoietin in egg whites. PLoS One. 2018; 13(5): e0194721.

21. Scott BB, Lois $C$. Generation of tissue-specific transgenic birds with lentiviral vectors. Proc Natl Acad Sci U S A. 2005; 102(45): 16443-7.

22. Park TS, Han JY. piggyBac transposition into primordial germ cells is an efficient tool for transgenesis in chickens. Proc Natl Acad Sci U S A. 2012; 109(24): 9337-41.

23. Lee HJ, Yoon JW, Jung KM, Kim YM, Park JS, Lee KY, Park KJ, Hwang YS, Park YH, Rengaraj D, Han JY. Targeted gene insertion into $\mathrm{Z}$ chromosome of chicken primordial germ cells for avian sexing model development. FASEB J. 2019; 33(7): 8519-29.

24. Oishi I, Yoshii K, Miyahara D, Tagami T. Efficient production of human interferon beta in the white of eggs from ovalbumin gene-targeted hens. Sci Rep. 2018; 8(1): 10203.

25. Eyal-Giladi H, Kochav S. From cleavage to primitive streak formation: a complementary normal table and a new look at the first stages of the development of the chick. I. General morphology. Dev Biol. 1976; 49(2): 321-337.

26. Hamburger $V$, Hamilton HL. A series of normal stages in the development of the chick embryo. 1951. Dev Dyn. 1992; 195(4): 231-272.

27. Bednarczyk M, Kozłowska I, Lakota P, Szczerba A, Stadnicka K, Kuwana T. Generation of transgenic chickens by the non-viral, cell-based method: effectiveness of some elements of this strategy. $J$ Appl Genet. 2018; 59(1): 81-9.

28. Carsience RS, Clark ME, Verrinder Gibbins AM, Etches RJ. Germline chimeric chickens from dispersed donor blastodermal cells and compromised recipient embryos. Development. 1993; 117(2): 669-75.

29. Kagami H, Clark ME, Verrinder Gibbins AM, Etches $R J$. Sexual differentiation of chimeric chickens containing ZZ and ZW cells in the germline. Mol Reprod Dev. 1995; 42(4): 379-87.

30. Kino K, Pain B, Leibo SP, Cochran M, Clark ME, Etches RJ. Production of chicken chimeras from injection of frozen-thawed blastodermal cells. Poult Sci. 1997; 76(5): 753-60.

31. Petitte JN, Clark ME, Liu G, Verrinder Gibbins AM, Etches RJ. Production of somatic and germline chimeras in the chicken by transfer of early blastodermal cells. Development. 1990; 108(1): 185-9.

32. Nakamura Y, Kagami H, Tagami T. Development, differentiation and manipulation of chicken germ cells. Dev Growth Differ. 2013; 55(1): 20-40.

33. Han JY, Lee HJ. Genome editing mediated by primordial germ cell in chicken. Methods Mol Biol. 2017; 1630: 153-63.

34. Cong L, Ran FA, Cox D. Multiplex genome engineering using CRISPR/Cas systems. Science. 2013; 339: 819-23.

35. Joung JK, Sander JD. TALENs: A widely applicable technology for targeted genome editing. Nat Rev Mol Cell Biol. 2013; 14: 49-55.

36. Urnov FD, Rebar EJ, Holmes MC, Zhang HS, Gregory $P D$. Genome editing with engineered zinc finger nucleases. Nat Rev Genet. 2010; 11(9): 636-46.

37. Gaj T, Gersbach CA, Barbas CF 3rd. ZFN, TALEN, and CRISPR/Cas-based methods for genome engineering. Trends Biotechnol. 2013; 31(7): 397-405.

38. Walsh RM, Hochedlinger $K$. A variant CRISPR-Cas9 system adds versatility to genome engineering. Proc Natl Acad Sci U S A. 2013; 110(39): 15514-5.

39. Wyman $C$, Kanaar $R$. DNA double-strand break repair: all's well that ends well. Annu Rev Genet. 2006; 40: 363-83.

40. Hsu PD, Lander ES, Zhang F. Development and applications of CRISPR-Cas9 for genome engineering. Cell. 2014; 157(6): 1262-78.

41. van de Lavoir MC, Diamond JH, Leighton, PA, MatherLove C, Heyer BS, Bradshaw R, Kerchner A, Hooi LT, Gessaro TM, Swanberg SE, Delany ME, Etches RJ. Germline transmission of genetically modified primordial germ cells. Nature. 2006; 441(7094): 766-9.

42. Shin SS, Kim TM, Kim SY, Kim TW, Seo HW, Lee SK, Kwon SC, Lee GS, Kim H, Lim JM, Han JY. Generation of transgenic quail through germ cell-medi- 
ated germline transmission. FASEB J. 2008; 22(7): 2435-44.

43. Macdonald J, Taylor L, Sherman A, Kawakami K, Takahashi Y, Sang HM, McGrew MJ. Efficient genetic mod-ification and germ-line transmission of primordial germ cells using piggyBac and Tol2 transposons. Proc Natl Acad Sci U S A. 2012; 109(23): E1466-E1472.

44. Kaewmanee T, Benjakul S, Visessanguan W. Changes in chemical composition, physical properties and micro-structure of duck egg as influenced by salting. Food Chem. 2009; 112(3): 560-9.

45. Carson $S$, Miller H, Witherow D. Characterization of Recombinant Clones. Molecular Biology Techniques. 2012: 67-76.

46. Cormack BP, Valdivia RH, Falkow S. FACS-optimized mutants of the green fluorescent protein (GFP). Gene. 1996; 173(1): 33-8.

47. Konoval O, Lu L, Tabaka P, Ren J, Bu X, Kostenko S, Du X, Chen L, Zhejiang Academy of Agricultural Sciences, Photoelectric method for sex detection of poultry, 2018,CN108575805B

48. Tagirov MT. Poluchenie himer germinativnoj linii ptic. Biotechnologia Acta. 2010; 3(2): 82-8.

49. Lucas A, Jamroz C. Atlas Of Avian Hematology. Washington D.C.: US Department of Agriculture; 1961; 271p.

50. Reynaud $G$. Reproductive capacity and offspring of chickens submitted to a transfer of primordial germ cells during embryonic life. Wilehm Roux Arch Dev Biol. 1976; 179(2): 85-110.

51. Watanabe M, Sugimori Y. Studies on the artificial insemination in ducks. Journal of the Faculty of Fisheries and Animal Husbandry. 1957; 3: 119-24.

52. Li H, Song W, Shu J, Chen K, Zhu W, Han W, Xu W. Genetic diversity and population structure of 10 Chinese indigenous egg-type duck breeds assessed by microsatellite polymorphism. J Genet. 2010; 89(1): 65-72.

53. Kostenko S, Konoval O, Chepiha A, Korol P, Doroshenko $M, L u L, B u X$, Huang $L$, Huang $X$, Li L. Genetic diversity and population structure of shaoxing and shanma ducks breeds by microsatellite loci. Scientific Bulletin of NULES of Ukraine. 2017; 271: 110-21.
54. Sechman A, EAkota P, Wojtysiak D, Hrabia A, Mika M, Lisowski M, Bednarczyk M. Sex steroids level in blood plasma and ovarian follicles of the chimeric chicken. J Vet Med A Physiol Pathol Clin Med. 2006; 53(10): 501-8.

55. Kamihira M, Ono K, Esaka K, Nishijima $K$, Kigaku R, Komatsu H, Yamashita T, Kyogoku K, Iijima $S$. High-level expression of single-chain FvFc fusion protein in serum and egg white of genetically manipulated chickens by using a retroviral vector. $J$ Virol. 2005; 79(17): 10864-74.

56. Wang ZB, Du ZQ, Na W, Jing JH, Li YM, Leng L, Luan $P$, Wu $C Y$, Zhang $K$, Wang $Y X$, Liu $W L$, Yuan $H$, Liu ZH, Mu YS, Meng QW, Wang $N$, Yang $\mathrm{CX}, \mathrm{Li} H$. Production of transgenic broilers by non-viral vectors via optimizing egg windowing and screening transgenic roosters. Poult Sci. 2019; 98(1): 430-9.

57. Penno CA, Kawabe Y, Ito A, Kamihira M. Production of recombinant human erythropoietin/Fc fusion protein by genetically manipulated chickens. Transgenic Res. 2010; 19(2): 187-195.

58. Korol P. Creation of transgenic, germinative chimeras of ducks using the CRISPR/Cas9 genome editing system (translated from Ukrainian). In: Aktualni Doslidzhennia Z Problem Rozvedennia, Henetyky Ta Biotekhnolohii U Tvarynnytstvi:Materialy XVIII Vseukrainskoi naukovoi konferentsii molodykh uchenykh i aspirantiv z mizhna-rodnoiu uchastiu, prysviachenoi 95-y richnytsi vid dnia narodzhennia profesora Volodymyra Yukhymovycha Nedavy. Chubynske: NAAN, In-t rozvedennia i henetyky tvaryn imeni M.V.Zubtsia; za red. Yu. P. Polupana; 2020: 16-7.

59. Korol P, Konoval O, Lu L, Bu X, Huang X, Li L. Creation of transgenic duck chimeras using the CRISPR/Cas9 genome editing system by the microinjection method (translated from Ukrainian). In: Aktualni Doslidzhennia Z Problem Rozvedennia, Henetyky Ta Biotekhnolohii U Tvarynnytstvi: Materialy XIX Vseukrainskoi Naukovoi Konferentsii Molodykh Uchenykh I Aspirantiv Z Mizhnarodnoiu Uchastiu. Chubynske: NAAN, In-t rozvedennia i henetyky tvaryn imeni M.V.Zubtsia; za red. Yu. P. Polupana; 2021: 8-9. 


\section{Створення трансгенної качки (Anas Platyrhynchos) за використання бластодермальних клітин та методу CRISPR/CAS9 \\ О. М. Коновал, П. В. Король, С. О. Костенко, П. П. Табака, Л. Ліжі, А. М. Чепіга, М. С. Дорошенко, О. В. Сидоренко, П. П. Джус, Н. П. Свириденко, Т. В. Литвиненко, Х. Бу, Х. Сюетао, Л. Лі, М. В. Драгулян, С. Р. Костюк, П. О. Філіпова}

Метою роботи була розробка методики створення трансгенних химер качок за використання донорських бластодермальних клітин після трансфекції 3 плазмідною ДНК та ліпофектаміном. Систему CRISPR/Cas9 з гомологічно спрямованою репарацією (HDR) використовували для редагування цільового сайту генома качки. Матеріали та методи. За використання бластодермальних клітин донорів після трансфекції з ДНК вектору з ліпофектаміном створені трансгенні химери качки. Для редагування цільової ділянки геному качки використали систему CRISPR/Cas9 з гомологічно направленою репараці$є ю$ (HDR). В якості трансгена використали репортерний ген EGFP. Висновки. 3200 яєць, в які були введені трансфіковані бластодермальні клітини, отримали 20 нащадків, у тому числі 8 самців і 12 самок. Таким чином, виживаність ембріонів склала $10 \%$. Серед виживших плідними виявилися 13/20 тварин G0 (65 \%): 10/12 (83.3\%) самок та 3/8 (37.5\%) самців. Процедура отримання химер сильніше впливає на виживаність та плідність самцівхимер. Від 13 з 20 птахів G0, отримали в цілому 197 нащадків (в т.ч. 117 (59.4\%) дочок і 80 (40.6\%) синів) з яких 59 були EGFP-позитивними (30.3\%), в тому числі 10 самців (16.9\%) і 49 самок (83.1\%). Використана нами методика може бути успішно застосована у подальших дослідженнях та при створенні трансгенної качки.

Кл ю ч о в і сл о в а: CRISPR/Cas9, EGFP, трансгенна качка, бластодермальні клітини, химера

\author{
Создание трансгенной утки (Anas Platyrhynchos) \\ с использованием бластодермальных клеток \\ и метода CRISPR / CAS9 \\ О. Н. Коновал, П. В. Король, С. А. Костенко, \\ П. П. Табака, Л. Лижи, А. М. Чепига, \\ М. С. Дорошенко, А. В. Сидоренко, П. П. Джус, \\ Н. П. Свириденко, Т. В. Литвиненко, Х. Бу, \\ Х. Сюетао, Л. Ли, М. В. Драгулян, Е. Р. Костюк, \\ П. А. Филиппова
}

Целью работы являлась разработка методики создания трансгенных химер уток с использованием донорских бластодермальных клеток после трансфекции с плазмидной ДНКи липофектамином. СистемуCRISPR/Cas9 с гомологически направленной репарацией (HDR) использовали для редактирования целевого сайта генома утки. Материалы и методы. Трансгенные химеры уток были созданы с использованием донорских бластодермальных клеток после трансфекции с векторной ДНКилипофектамином. Для редактирования целевой области генома утки мы использовали систему CRISPR/ Cas9 с гомологично направленным востановлением поврежденной ДНК (HDR). В качестве трансгена использовали репортерный ген EGFP. Выводы. Из 200 яиц, в которые были внесены трансфицированные бластодермальные клетки, было получено 20 потомков, в том числе 8 самцов и 12 самок. Таким образом, выживаемость эмбрионов составила $10 \%$. Среди выживших фертильных животных было 13/20 животных G0 (65 \%): 10/12 (83,3\%) самок и 3/8 (37,5\%) самцов. Процедура получения химер сильнее влияет на выживаемость и плодовитость самцов химер. Всего от 13 из 20 птиц G0 получено 197 потомков (в том числе 117 $(59,4 \%$ ) дочерей и 80 (40,6 \%) сыновей), из которых 59 были EGFP-положительными (30,3\%), в том числе 10 самцов $16,9 \%$ и и 49 самок. (83,1 \%). Используемая нами методика может быть успешно применена в дальнейших исследованиях и при создании трансгенной утки.

Кл юч е вы е сл о в а: CRISPR/Cas9, EGFP, трансгенная утка, бластодермальные клетки, химера.

Received 20.06.2021 